\title{
Positive aging: the relationship between emotional intelligence and psychological, social and physical wellbeing
}

\begin{abstract}
Nowadays ageing in a healthy way is one of the greatest challenges of our era. There are several factors associated with the emotional functioning of an individual which are necessary for managing and regulating emotional life, such as perceiving and understanding emotions and being able to regulate them. Such abilities are well encompassed by the Emotional Intelligence (EI) construct. An impressive body of literature indicates that EI has a significant influence on psychological, social and physical health. However, to date, such evidence cannot be extended accurately to the older population as the vast majority of studies have been focused on samples composed of adolescents and young adults. Therefore the aim of the current review is to analyze what extent is linked to psychosocial and physical functioning among older people.
\end{abstract}

Keywords: emotional intelligence, older adults
Volume 3 Issue I - 2018

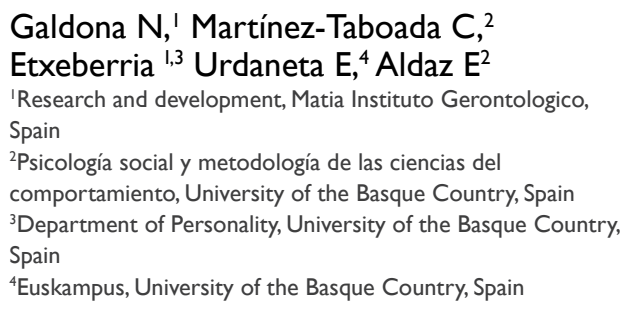

Correspondence: Cristina Maritnez-Taboada, Psicología social y metodología de las ciencias del comportamiento, University of the Basque Country, Spain, Email cristinamtk@gmail.com

Nerea Galdona Erquicia, Research and development, Matia Instituto Gerontologico, Spain,

Email nerea.galdona@matiafundazioa.eus

Received: December 01, 2017 | Published: January 03, 2017

\section{Introduction}

The management of emotions is a powerful predictor of psychological well-being and health during all periods of life. Although everyone experiences emotions, people clearly differ in the ways to which they deal with intrapersonal or interpersonal emotional information. ${ }^{1}$ Besides the individual differences in emotional management, studies conducted from a life course perspective indicate an affective stability and a high level of emotional wellbeing among older adults ${ }^{2,3}$ arguing therefore the importance of promoting positive emotional performance in older adults due to its potential benefit in their daily functioning.

\section{Emotional intelligence in older people}

Emotional Intelligence (EI) is recognized by numerous studies over the last decades to have a significant impact on psychological, social and physical adjustment. ${ }^{4}$ However most of those findings are related to young and middle aged samples and little is known about the association between EI and well-being among older people. Therefore, the aim of the current review is to summarize to what extent EI is linked to psychological, social and physical functioning among elderly.

EI construct encompassed the ability to perceive, to understand emotions and to be able to regulate them. ${ }^{5}$ Salovey \& Mayer ${ }^{6}$ first proposed the term EI to refer to a set of interrelated skills that allow an individual to recognize, to comprehend, to use and control emotional episodes in an efficient and adaptive manner. Thereby they allow effective dealings with the environment. Further considerations of those authors ${ }^{7}$ suggested that EI meets a developmental criterion: EI develops with age and experience from childhood to early adulthood. For this reason, and may be because of that, of the study of emotional resources as a helpful skills in the aging process start much later. The vast majority of studies have focused on samples of adolescents and young adults. Actually more recent research on EI has extended the adult age range to include older adults. Those studies have found that elderly have significantly higher scores than young adults in EI. ${ }^{8-11}$ Meanwhile, according to Galdona ${ }^{12}$ EI is configured similarly in middle-aged adults (from 50 to 65 years old) and older adults (from 66 to 90 years old). The study revealed only age differences between young and middle aged adults, and between young and older adults. There were as well higher levels of EI among middle aged and older adults. This positive relationship between age and EI might be explained due to the lifelong learning the accumulated knowledge and experience acquired in life. ${ }^{13}$ Being EI considered as a powerful resource for the aging process due to the fact that it's improve or remain stable with time. In the contrary there are some other aspects susceptible to decline with age such as physical health, income and cognitive capacities.$^{14,15}$ Recent research has analyzed the relationship between EI and psychological, social and physical functioning among older adults. We conducted a non-systematic review. We used PubMed search terms including "elderly" or "older adults", "health", "wellbeing", "social support" or "social functioning" and included publications selected based on knowledge generated from our research in this field as well as our experience from working with formal and informal caregivers. Some of the most interesting findings are summarized below.

\section{Emotional intelligence and psychological functioning}

The relationship between EI and psychological functioning has been analyzed in an important number of studies. These studies have indicated that EI is associated with a higher degree of life 
satisfaction. ${ }^{16-18,8,12}$ In line with those studies Galdona ${ }^{12}$ found a relevant finding between perceived EI and life satisfaction. Perceived EI is the ability to pay attention to emotions, to understand and regulate them. In this study, the emotional clarity and repair dimensions of perceived EI predicted life satisfaction and positive affect in a sample with age ranging from 50 to 90 years old. According to this, a longitudinal study showed that emotional clarity and repair predicted psychological wellbeing and that, conversely, attention to feelings (the third component of the perceived EI) forecast emotional distress. ${ }^{18}$ These results of the relationship between EI and psychological wellbeing suggest that emotionally intelligent people are likely to experience higher levels of psychological wellbeing and lower levels of emotional impairment that individuals with a low levels of EI. ${ }^{18-20}$

\section{Emotional intelligence and social functioning}

Another factor is the association between EI and social support. Previous research with young and middle aged people has shown a positive association. That is to say that higher EI is related to increased social support. ${ }^{21}$ and better quality of social and marital relationships. ${ }^{22}$ Research on emotional clarity and repair ${ }^{12}$ were positively and significantly related to social support among elderly. These emotional competencies are thought to be important for social interaction. Emotions serve as communicative and social functions, conveying information about people's thoughts and intentions and coordinating positive social encounters. ${ }^{23}$

\section{Emotional intelligence and health}

Finally, interactions between EI and physical health and healthy behaviors ${ }^{24-26}$ have been focused on young and middle aged adults. These findings indicate that higher EI is linked to better physical health; both subjectively and objectively reported. ${ }^{25-26}$ Consequently, given the number of health benefits associated with EI, a logical extension would be to apply these studies with older adults. This is a population that must cope with different physical challenges related to the ageing process. ${ }^{27}$ However to date only a study has been found analyzing the relationship between EI and subjective health in older people. ${ }^{12}$ The results of this study revealed that attention to feelings is not related to subjective positive health although the association is lower as the age increases. This make sense since has been argued that high levels of emotional attention are related to psychological disorders like depression and anxiety. ${ }^{28}$ From the other hand, repair of emotions was related to positive perception of physical and mental health whereas the clarity to feelings was positively related only to perceived mental health aspects among older adults. ${ }^{12}$ In short, also in aging people there is a positive association between EI and physical health, at least on regards to the subjective health.

\section{Practical implications and future research}

The study of emotions is necessary to understand developmental trajectories throughout the lifespan..$^{29,30}$ In particularly the study of EI during aging is relevant because age has been shown to be a modulator variable that means to provide strategies for adaptation at this stage of life. Specific competences like EI are fundamental for a healthier psychological, social and physical life functioning at all ages, especially in ageing, where older people must cope with different physical, social and personal challenges related to the ageing process. ${ }^{31,32}$
The results provided by different studies are discussed in the present review. They suggest a functional importance for studying EI in older adults, and a need to address this line of research more thoroughly. Thus, more research is needed to know the relationship between EI and diverse variables like psychological, social and physical functioning. A fact is that precisely EI can be improved and is trainable in older people. ${ }^{33,34}$ Psychological intervention programs should focused on training EI competence with a lifelong perspective due to the fact that when EI is enhanced through training, psychological, physical and social adjustment improve. ${ }^{35}$

On the other hand, given the importance of emotional competencies in social interaction, future studies should also explore the relationship between EI and other variables such as social support and loneliness ${ }^{36}$ where scarce research has been found in regards to elderly.

Finally this review highlights the relevance of EI in psychological, social and physical health especially in older people. More emotionally intelligence seniors would contribute to healthier societies, in terms of well-being, quality of social relationships, as well as, less health care expenditures related to positive aging.

\section{Acknowledgements}

None.

\section{Conflict of interest}

Author declare that there is no conflict of interest in publishing the manuscript.

\section{References}

1. Petrides KV, Furnham A. Trait emotional intelligence: Behavioural validation in two studies of emotion recognition and reactivity to mood induction. Eur J Pers. 2003;17(1):39-57.

2. Kessler EM, Staudinger UM. Affective experience in adulthood and old age: The role of affective arousal and perceived affect regulation. Psychol Aging. 2009;24(2):349-362.

3. Scheibe S, Carstensen LL. Emotional aging: Recent findings and future trends. J Gerontol B Psychol Sci Soc Sci. 2010;65(2):135-144.

4. Mikolajczak M, Van Mellegen S. Increasing emotional intelligence to decrease healthcare expenditures: how profitable would it be? Pers Indiv Differ. 2017;116(1):343-347.

5. Petrides KV. Ability and trait emotional intelligence. In: Chamorro PT, Stumm S, editors. The Wiley-Blackwell handbook of individual differences, NY: Wiley, 2011. p. 656-678.

6. Salovey P, Mayer JD. Emotional intelligence. Imagin Cog Pers. 1990;9(3):185-211.

7. Mayer JD, Caruso DR, Salovey P. Selecting a measure of emotional intelligence: The case for ability scales. In: Bar-On, R Parker, editors. The handbook of emotional intelligence: Theory, development, assessment, and application at home, school, and in the workplace. CA: Jossey-Bass, USA; 2000. p. 320-342.

8. Chen P, Peng Y, Fang P. Emotional intelligence mediates the relationship between age and subjective well-being. Int J Aging Hum Dev. 2016;83(2):91-107.

9. Gardner KJ, Qualter P. Factor structure, measurement invariance and structural invariance of the MSCEIT V2.0. Pers Indiv Diff. 2011;51(4):492-496. 
10. Navarro B, Latorre J, Ros L. Inteligencia emocional autoinformada en la vejez, un estudio comparativo conel TMMS-24. In: Fernández PB, N Extremera, editors. Avances en el estudio de la inteligencia emocional. Santander: Fundación Marcelino Botín; 2009. p. 217-222.

11. Tsaousis I, Kazi S. Factorial invariance and latent mean differences of scores on trait emotional intelligence across gender and age. Pers Indiv Differ. 2013;54(2):169-173.

12. Galdona N. Influencia de las variables psicosociales en la salud y el bienestar subjetivo en tres momentos del ciclo vital (tesis doctoral). Spain; 2011.

13. Kaufman AS, Johnson CK, Liu X. A CHC theory-based analysis of age differences on cognitive abilities and academic skills at ages 22 to 90 years. J Psychoeduc Assess. 2008;26(4):350-381.

14. Charles S. Strength and vulnerability integration: A model of emotional well-being across adulthood. Psychol Bull. 2010;136(6):1068-1091.

15. Mather M. The emotion paradox in the aging brain. Ann N Y Acad Sci. 2012;1251(1):33-49.

16. Amdurer E, Boyatzis RE, Saatcioglu A, et al. Long term impact of emotional, social and cognitive intelligence competencies and GMAT on career and life satisfaction and career success. Front Psychol. 2014;5:1447.

17. Delhom I, Gutierrez M, Lucas MB, et al. Emotional intelligence in older adults: Psychometric properties of the TMMS-24 and relationship with psychological well-being and life satisfaction. Int Psychogeriatr. 2017;29(8):1327-1334.

18. Shulman T, Hemenover S. Is dispositional emotional intelligence synonymous with personality? Self Identity. 2006;5:147-171.

19. Li X, Zheng X. Adult attachment orientations and subjective wellbeing: Emotional intelligence and self-esteem as moderators. Soc Behav Personal. 2014;42(8):1257-1266.

20. Carmeli A, Yitzhak HM, Weisberg J. The relationship between emotional intelligence and psychological wellbeing. J Manage Psychol. 2009;24(1):66-78.

21. Mikolajczak M, Luminet O, Leroy C, et al. Psychometric properties of the trait emotional intelligence questionnaire: Factor structure, reliability, construct, and incremental validity in a French-speaking population. $J$ Person Assess. 2007;88(3):338-353.

22. Petrides KV, Sangareau Y, Furnham A, et al. Trait Emotional Intelligence and Children's Peer Relations at School. Soc Develop. 2006;15:537-547.

23. Keltner D, Haidt J. Social functions of emotions. In: TJ Mayne, GA Bonanno, editors. Emotions: Current issues and future directions. Emotions and social behavior New York: Guilford; 2001. p. 192-213.
24. Bauld R, Brown RF. Stress, psychological distress, psychosocial factors, menopause symptoms and physical health in women. Maturitas. 2009;62:160-165.

25. Martins A, Ramalho N, Morin E. A comprehensive meta-analysis of the relationship between Emotional Intelligence and health. Person Indiv Differ. 2010;49(6):554-564.

26. Mikolajczak M, Avalosse H, Vancorenland S, et al. A nationally representative study of emotional competence and health. Emotion. 2015;15(5):653-667.

27. Smith J, Borchelt M, Maier H, et al. Health and well-being in the young old and the oldest old. J Soc Issues. 2002;58(4):715-732.

28. Salovey P, Woolery A, Stroud L, et al. Perceived emotional intelligence, stress reactivity and symptom reports: Furthers explorations using the Trait Meta-Mood Scale. Psychol Health. 2002;77(5):611-627.

29. Álvarez BJA, Pérez FMC, Berenguel AI, et al. Programa informático de estimulación cognitiva e inteligencia emocional para personas mayores (PECI-PM) [Computer program of cognitive stimulation and emotional intelligence for older citizens]. Almería: ASUNIVEP, 2013. p. 267-274.

30. Lynchard NA, Radvansky GA. Age-related perspectives and emotion processing. Psychol Aging. 2012;27(4):934-939.

31. Bernarás E, Garaigordobil M, las Cuevas C. Inteligencia emocional y rasgos de personalidad: influencia de la edad y el género durante la edad adulta y la vejez. Bol Psicol. 2011;103:75-88.

32. Hogan S, Warren L. Dealing with complexity in research processes and findings: how do older women negotiate and challenge images of aging. J Women Aging. 2012;24(4):329-350.

33. Etxeberria I, Galdona N, Aldaz E, et al. Beneficios en el bienestar emocional de personas mayores tras la aplicación del programa de educación socioemocional "Sentimenduz". Rev Esp Geriatr Gerontol. 2012;47:17.

34. Soldevila A, Ribes R, Filella G, et al. Objetivos y contenidos de un programa de educación emocional para personas mayores. Emociona't Rev Iberoam Educ. 2005;37:5.

35. Nelis D, Kotsou I, Quoidbach J, et al. Increasing emotional competence improves psychological and physical wellbeing, social relationships, and employability. Emotion. 2011;11(2):354-366.

36. Lopes PN, Brackett MA, Nezlek JB, et al. Emotional intelligence and social interaction. Pers Soc Psychol Bull. 2004;30(8):1018-1034. 